\title{
Succession study on forensically important Coleoptera from India: a preliminary study and its forensic implications
}

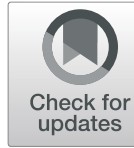

\author{
Neha Singh ${ }^{1^{*}}$ and Madhu Bala ${ }^{2}$
}

\begin{abstract}
Background: Coleoptera is the second most important group of entomofauna associated with decomposition, yet little is known about its role in decomposition and postmortem colonization of carcasses in India and other parts of the world. Consequently, a preliminary study was conducted to study the succession of forensically important Coleoptera using goat carrion as an animal model.

Results: Five decomposition stages were observed during the experiment. A total of 1174 adult coleopterans belonging to 21 species and seven families were collected during this study. Throughout faunal succession, Histeridae and Silphidae were the dominant Coleopteran families, and they occurred mainly during the bloated and decay stages of decomposition; Necrophila (Calosilpha) ioptera was the dominant species present from the bloated to dry stage of putrescence. Two species, Pachylister bellicus and Saprinus sternifossa were reported for the first time from India.

Conclusion: This study provides baseline data regarding Coleopteran species associated with different decomposition stages, but more extensive studies need to be performed to develop a geographical database on arthropod succession from as many habitats as possible so that this kind of data can be used in forensic cases.
\end{abstract}

Keywords: Forensic entomology, Carrion, Decomposition, Insect succession, Coleoptera

\section{Background}

Forensic entomology applies evidence from insect to legal problems such as the estimation of the minimum postmortem interval (mPMI). It is, therefore, indispensable to know the insect fauna that is attracted to humans across varied geographic regions (Shin et al. 2015). Animal carcasses are widely used as experimental models to study faunal succession as they are a temporary and rapidly changing food source to many creatures. Insects, especially Diptera and Coleoptera, are generally the first to arrive because they are attracted by different odors and gases that are released by a carcass, and they use it as a source of food, reproduction, and larval development (Cornaby 1974). The environmental factors such as temperature, humidity, rainfall, season, and micro-climate of the surrounding postmortem habitat

\footnotetext{
* Correspondence: nehasinghko@gmail.com

'Department of Zoology \& Environmental Sciences, Punjabi University,

Patiala, India

Full list of author information is available at the end of the article
}

play a significant role in the determination of insect fauna on carrion, and they may combine differently at different crime scenes. If these factors are not considered, a falsifying effect on the accuracy of the mPMI estimate may emerge (Eberhardt \& Elliot 2008).

Flies are used primarily as entomological evidence to estimate $\mathrm{mPMI}$, and beetles have been found to be the primary entomological evidence for a corpse in the advanced decomposition stage but their usefulness to estimate the mPMI needs to be emphasized (Kulshrestha \& Satpathy 2001). According to Villet (2011), the families of Coleoptera that are of forensic importance are Silphidae, Histeridae, Staphylinidae, Dermestidae, Cleridae, Trogidae, and Scarabaeidae. The scarcity of data on the ecology and behavior of beetles is the main hurdle in using them as forensic evidence. However, knowledge on the ecology of forensically important beetles could not only help in PMI/PAI estimation (Matuszewski 2011, 2012; Souza et al. 2014), but also be used to support mPMI estimates from Dipteran data 
(Goff \& Flynn 1991). The fact that beetles populate at the corpse later than flies likely defines their specificity with a particular stage of decomposition (Varatharajan \& Sen 2000) or as a form of adaptation to reduce competition with flies (Smith 1986). Beetles can be used as mPMI indicators, but knowledge of their biology and life cycle is essential to be used along with the expertise on systematic evidence. There are various studies where beetles have been observed on human corpses (Kulshrestha \& Satpathy 2001; Barreto et al. 2002; Sukontason et al. 2007; Mariani et al. 2014; Sharma et al. 2018, MoemenbellahFard 2018). Moreover, some studies have shown the successful implication of beetle data collected from the human corpse to estimate the postmortem interval (Kumara et al. 2009; Ridgeway et al. 2013).

It is well established that arthropod appearance on carrion follows a predictable sequence (Payne 1965; Rodriguez \& Bass 1983; Early \& Goff 1986; Anderson \& VanLaerhoven 1996; Grassberger \& Frank 2004; Tabor et al. 2004; Gill, 2011) at the family level. The mPMI can be estimated by comparing the taxa found on human carrion with the known succession patterns in that particular habitat or geographical area using the animal models under controlled conditions (Tabor et al. 2005). Most of the families that are attracted to corpses are ubiquitous; however, their distribution can vary across regions which emphasize the need to perform local studies (Castro et al. 2013).

The purpose of this study was to observe the process of beetle succession using a goat carcass and identify different beetles that are associated with various stages of decomposition to provide baseline data. The current study was limited by a small sample size and was preliminary, but the data provides a summary of some of the forensically important beetles.

\section{Material and methods}

\section{Study area}

The experiment was performed during May 2014 ( $2^{\text {nd }}$ 16th) in Kullu, Himachal Pradesh, India. This area is a broad open valley, with the highest temperatures ranging from 24 to $34{ }^{\circ} \mathrm{C}$ from May to August. During December and January, the lowest temperatures are observed, which range from -4 to $20{ }^{\circ} \mathrm{C}$ and is accompanied by some snowfall. The average annual rainfall is $800 \mathrm{~mm}$.

The study was conducted in a private orchid farm $\left(31^{\circ}\right.$ $57^{\prime} 35.9^{\prime \prime} \mathrm{N}, 77^{\circ} 07^{\prime} 21.8^{\prime \prime} \mathrm{E}$ ). The site is away from the urban area of the main city and was selected to avoid disturbances. The vegetation is characterized by native shrubs and apple, plum, almond, and permission trees, and the local vertebrate fauna comprises wild dogs, jackals, snakes, and lizards.

For the collection purposes, goat carrion weighing about $3 \mathrm{~kg}$ was used and covered with a cage $(24 \times 20 \times 9$ in) to prevent the scavengers. There were three replicates of the experiment $(n=3)$, separated each other by a distance of $600 \mathrm{~m}$. Carcasses were partially in the shade depending upon the time of the day.

\section{Insect collection and identification}

Sampling was done by thoroughly inspecting the carrion during which adult specimens were collected with the help of forceps with minimum disturbance. The collection began $24 \mathrm{~h}$ after placing the carrion and was done two times a day, morning and evening, till the 11th day of decomposition, after which it took place once a day until skeletonization of the carrion. Temperature and relative humidity at the main and replicate experimental sites were recorded at the time of sampling using a portable thermo-hygrometer.

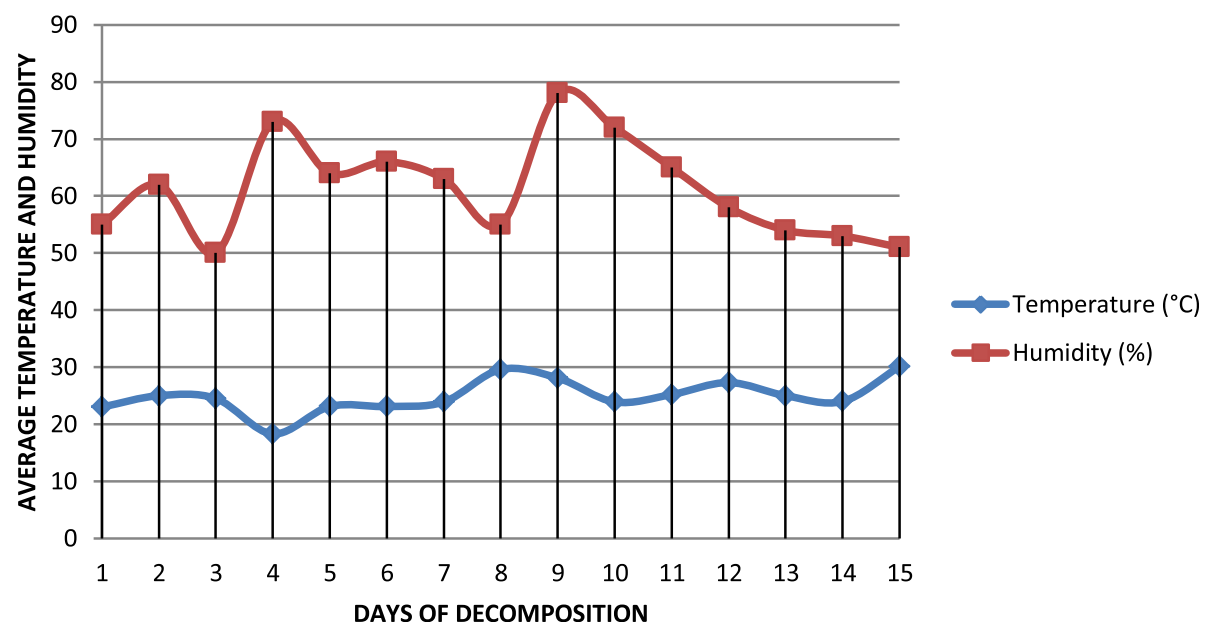

Fig. 1 Meteorological data showing average temperatures and humidity during the experiment. This figure describes the average temperature and humidity of each day during the whole decomposition process 
All adult beetles were collected regardless of their behavior or feeding habits on the carrion. Collected specimens were categorized as necrophagous and nonnecrophagous on the basis of their feeding behavior. Necrophagous beetles consisted of the ones which were observed feeding upon the decaying meat while the rest was considered as non-necrophagous. Collected fauna was stored in $70 \%$ alcohol in vials at the site until they were brought to the laboratory for the identification with the help of taxonomic keys (Peacock 1993; Ruzicka \& Schneider 1996, 2002, 2011; Ruzicka et al. 2000, 2011, 2015). Beetle larvae belonging to silphids and dermestids were collected as an entity, but not identified to the species level; hence, they were not included in the study.
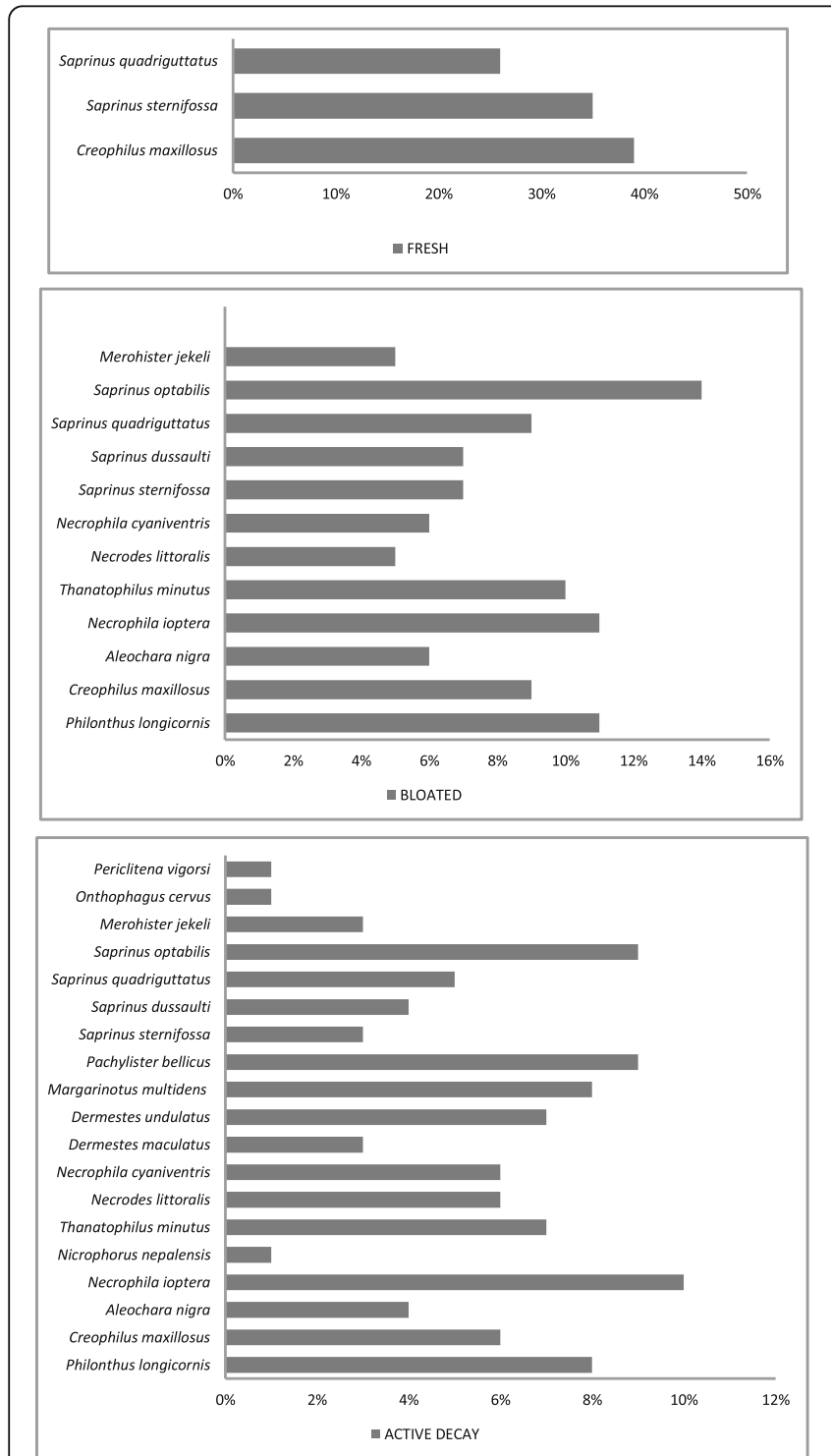

\section{Data analysis}

The variation of species with each decomposition stage and their feeding habits were analyzed with the Kruskal-Wallis test (Minitab 18). Chi-square was performed for comparison between necrophagous and nonnecrophagous species in all replicates using a 5\% confidence level.

\section{Results}

\section{Meteorological data}

The average ambient temperature and relative humidity were $24.9{ }^{\circ} \mathrm{C}$ and $61.2 \%$, respectively, at all sites (Fig. 1). There was no significant change observed during replicates in terms of decomposition stages $(P>0.05$, D.F. $=2)$.
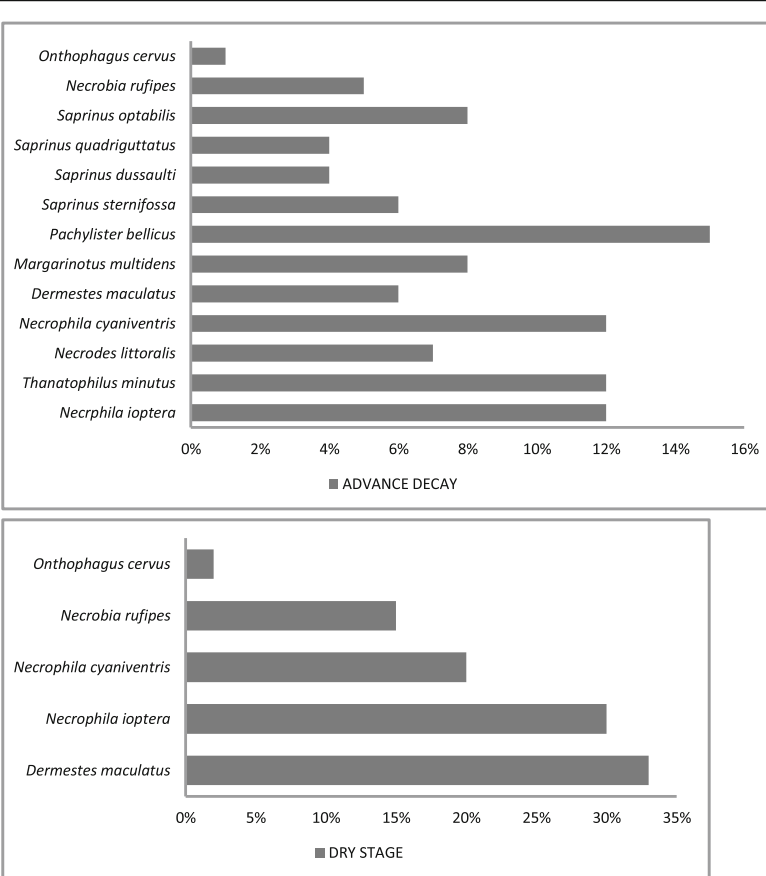

Fig. 2 Composition of Coleoptera (species) during five decomposition stages. These charts explain the percentage of each species found at every stage of decomposition during experiment 


\section{Decomposition process}

Complete decomposition occurred in 15 days. Five decomposition stages were observed (fresh, bloated, active decay, advanced decay, and dry) in all the replicates which were in accordance with the stages mentioned by Anderson and VanLaerhoven (1996), and the composition of beetle species at each decomposition stage is shown in Fig. 2.

\section{Beetle community and feeding habits}

We collected 1174 adult coleopterans from 21 species and seven families during this study. Species richness and abundance reached a maximum (19 species) during the active decay stage, followed by the bloated and advanced decay stages having 13 species each, while the minimum number of species were observed during the fresh stage (Fig. 2). The chronological sequence of their arrival in relation to the decomposition days with all replicates is shown in Table 1. The Kruskal-Wallis test (Minitab 18) showed that there was no statistically significant difference between the number of individuals and families found at each decomposition stage among all replicates $(P=0.993 \geq 0.05$, D.F. $=2)$. Beetle species of different feeding habits (Table 2) were divided into two categories of necrophagous and non-necrophagous. In terms of abundance, no significant difference was found between necrophagous and non-necrophagous species in all three replicates $\left(\chi^{2}=1.037, P>0.05\right.$, D.F. $\left.=2\right)$.

\section{Discussion}

As previously discussed, insects play a significant role in the decomposition process, and they are intimate witnesses to the postmortem phase of carcasses (Krikken \& Huibregts 2001); however, there are several factors that can affect the colonization of insects on carrion, and these factors can alter the rate of decomposition progression. Rainfall is a factor that can affect the rate of decomposition since rain can soak the carcass and expel fly larvae (Lyu et al. 2016). In this study, increased maggot activity was observed after a night of rainfall on the 9th day of decomposition.

A high proportion of beetles were collected during the early stages of decomposition, which is in contrast to previous studies that suggest the coleopterans do not occupy carrion until later stages of decomposition. However, there

Table 1 List of all beetle species and their number found during this study

\begin{tabular}{|c|c|c|c|}
\hline Family & Species & No. of specimens (\%) & Feeding habit ${ }^{\#}$ \\
\hline \multirow[t]{3}{*}{ Staphylinidae } & Philonthus longicornis (Stephens, 1832) & $72(6.1 \%)$ & $\bar{P}$ \\
\hline & Creophilus maxillosus (Linnaeus, 1758) & $76(6.5 \%)$ & $\mathrm{P}$ \\
\hline & Aleochara nigra (Kraatz, 1859) & $40(3.4 \%)$ & $\mathrm{P}$ \\
\hline \multirow[t]{5}{*}{ Silphidae } & Necrophila (Calosilpha)ioptera (Kollar \& Redtenbacher,1848) & $130(11.1 \%)$ & N \\
\hline & Nicrophorus nepalensis (Hope, 1831) & $2(0.2 \%)$ & N \\
\hline & Thanatophilus minutus (Kraatz, 1876) & $95(8.1 \%)$ & $\mathrm{N}$ \\
\hline & Necrodes littoralis (Linnaeus, 1758) & $63(5.4 \%)$ & $\mathrm{N}$ \\
\hline & Necrophila (Calosilpha) cyaniventris (Motschulsky, 1870) & $90(7.7 \%)$ & $\mathrm{N}$ \\
\hline \multirow[t]{2}{*}{ Dermestidae } & Dermestes maculatus De Geer, 1774 & $49(4.2 \%)$ & $\mathrm{N}$ \\
\hline & Dermestes undulatus Brahm, 1790 & $31(2.7 \%)$ & $\mathrm{N}$ \\
\hline \multirow[t]{7}{*}{ Histeridae } & Margarinotus multidens (Schmidt, 1889) & $57(4.9 \%)$ & $\mathrm{P}$ \\
\hline & Pachylister bellicus* (Marseul,1884) & $73(6.2 \%)$ & $\mathrm{P}$ \\
\hline & Saprinus sternifossa* G.Muller, 1937 & $69(5.9 \%)$ & $P$ \\
\hline & Saprinus dussaulti Marseul, 1870 & $44(3.8 \%)$ & $P$ \\
\hline & Saprinus quadriguttatus (Fabricius, 1798) & $74(6.3 \%)$ & $P$ \\
\hline & Saprinus optabilis Marseul, 1855 & $107(9.1 \%)$ & $P$ \\
\hline & Merohister jekeli (Marseul,1857)Merohister jekeli (Marseul,1857) & $33(2.8 \%)$ & P \\
\hline Cleridae & Necrobia rufipes (De Geer, 1775) & $22(1.9 \%)$ & N \\
\hline \multirow[t]{2}{*}{ Scarabaeidae } & Onthophagus cervus (Fabricius,1801) & $10(0.9 \%)$ & C \\
\hline & Onthophagus sp. & $7(0.6 \%)$ & $\mathrm{O}$ \\
\hline Chrysomelidae & Periclitena vigorsi (Hope, 1831) & $3(0.3 \%)$ & $\mathrm{O}$ \\
\hline Total specimens & & 1174 & \\
\hline Total feeding categories & & & 4 \\
\hline
\end{tabular}

${ }^{\#} \mathrm{~N}$, necrophagous; $\mathrm{P}$, predator; $\mathrm{C}$, coprophagous; $\mathrm{O}$, others

*First time reported from India according to Mazur (2011) 
Table 2 Chronological sequence of beetle occurrence during different decomposition stages

\begin{tabular}{|c|c|c|c|c|c|c|c|c|c|c|c|c|c|c|c|c|c|}
\hline \multirow{2}{*}{\multicolumn{3}{|c|}{ Adult fauna }} & \multicolumn{15}{|c|}{ Days of decomposition } \\
\hline & & & \multicolumn{2}{|c|}{ Fresh } & \multicolumn{3}{|c|}{ Bloated } & \multicolumn{4}{|c|}{ Active decay } & \multicolumn{3}{|c|}{ Adv. decay } & \multicolumn{3}{|l|}{ Dry } \\
\hline S.No. & Family & Species & 1 & 2 & 3 & 4 & 5 & 6 & 7 & 8 & 9 & 10 & 11 & 12 & 13 & 14 & 15 \\
\hline \multirow[t]{3}{*}{1} & Staphylinidae & Philonthus longicornis & & & & & & & & & & & & & & & \\
\hline & & Creophilus maxillosus & & & & & & & & & & & & & & & \\
\hline & & Aleochara nigra & & & & & & & & & & & & & & & \\
\hline \multirow[t]{5}{*}{2} & Silphidae & Necrophila (Calosilpha) ioptera & & & & & & & & & & & & & & & \\
\hline & & Nicrophorus nepalensis & & & & & & & & & & & & & & & \\
\hline & & Thanatophilus minutus & & & & & & & & & & & & & & & \\
\hline & & Necrodes littoralis & & & & & & & & & & & & & & & \\
\hline & & Necrophila (Calosilpha) cyaniventris & & & & & & & & & & & & & & & \\
\hline \multirow[t]{2}{*}{3} & Dermestidae & Dermestes maculatus & & & & & & & & & & & & & & & \\
\hline & & Dermestes undulatus & & & & & & & & & & & & & & & \\
\hline \multirow[t]{7}{*}{4} & Histeridae & Margarinotus multidens & & & & & & & & & & & & & & & \\
\hline & & Pachylister bellicus & & & & & & & & & & & & & & & \\
\hline & & Saprinus sternifossa & & & & & & & & & & & & & & & \\
\hline & & Saprinus dussaulti & & & & & & & & & & & & & & & \\
\hline & & Saprinus quadriguttatus & & & & & & & & & & & & & & & \\
\hline & & Saprinus optabilis & & & & & & & & & & & & & & & \\
\hline & & Merohister jekeli & & & & & & & & & & & & & & & \\
\hline 5 & Cleridae & Necrobia rufipes & & & & & & & & & & & & & & & \\
\hline \multirow[t]{2}{*}{6} & Scarabaeidae & Onthophagus cervus & & & & & & & & & & & & & & & \\
\hline & & Onthophagus sp. & & & & & & & & & & & & & & & \\
\hline 7 & Chrysomelidae & Periclitena vigorsi & & & & & & & & & & & & & & & \\
\hline
\end{tabular}

are various reports in the literature supporting their early arrival on carcasses (Braack 1987; Midgley et al. 2010; Mayer \& Vasconcelos 2013). Histeridae and Staphylinidae were the first to arrive after $24 \mathrm{~h}$ of carrion placement, which supports the claim of the early arrival of coleopterans on carcasses. The fresh stage was dominated by predators from the families Staphylinidae and Histeridae: Creophilus maxillous (39\%), Saprinus quadriguttatus (35\%), and Saprinus sternifossa (26\%). During the bloated stage, out of the 13 species identified, the dominant

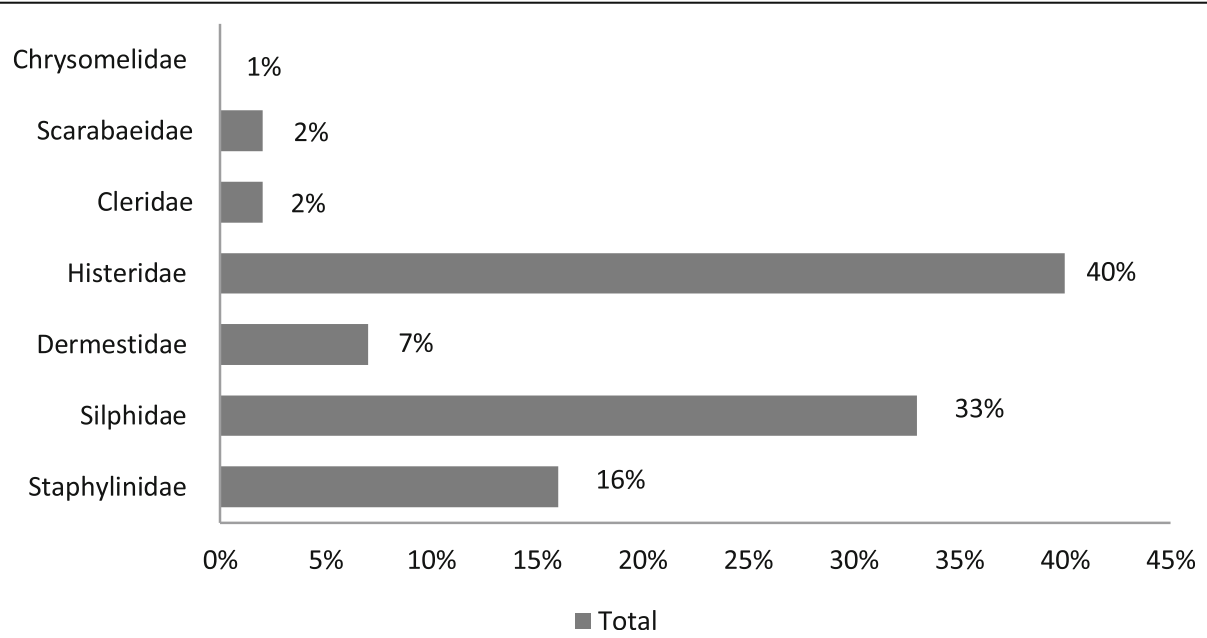

Fig. 3 Composition of Coleoptera (families) communities during decomposition. Bar chart explaining the number of specimens of seven families (\%) found during the experiment 
species were Philonthus longicornis (11\%), Necrophila (Calosilpha) ioptera (11\%), and Saprinus optabilis (14\%). Active decay was dominated by Necrophila (Calosilpha) ioptera (10\%). During advanced decay, when maggots and beetles had already devoured most of the flesh, the most abundant beetle species included Pachylister bellicus (15\%), Necrophila (Calosilpha) ioptera (12\%), and Necrophila (Calosilpha) cyaniventris (12\%). At the dry stage when mostly the bones remained, Dermestes maculatus (33\%) was dominant.

Histeridae (40\%, Fig. 3) had the highest species richness of all families, among which Saprinus optabilis was the most abundant species. Seven species of histerid beetles were collected, with Pachylister bellicus (during active decay) and Saprinus sternifossa (during bloated and active decay) being first time reported from India as per Mazur (2011). This demonstrates that studies like the current one are not only beneficial for forensic but are also of taxonomic importance.

The invasion of Silphidae (33\%) on the carrion began at the bloated stage, and they were maintained at a medium abundance during the active and advanced decay stages. Necrophila (Calosilpha) ioptera from this family was the dominant species in this study. Of the five species collected, Necrophila (Calosilpha) ioptera and Nercophila (Calosilpha) cyaniventris were present from bloated to dry stage whereas Thanatophilus minutus and Necrodes littoralis were present from the bloated to active decay stages (Fig. 2). Nercophila (Calosilpha) cyaniventris had been reported before similar studies conducted in India (Bharti \& Singh 2003). Nicrophorus nepalensis is a carrion-feeding beetle and is known to be attracted to small carrions (Hwang \& Shiao 2011), but there were only two specimens recorded during the active decay stage in this study. However, their appearance indicates its general presence in the study habitat and area.

Staphylinidae (16\%) was the third most abundant family found in this study (Fig. 3), and it was observed during the bloated and active decay. And it appeared with Creophilus maxillosus after $24 \mathrm{~h}$ of bait placement. Three species of this family (Philonthus longicornis, Creophilus maxillosus, and Aleochara nigra) appeared from the bloated to the active decay stages and preyed on fly larvae, showing predatory behavior of these species on maggots as reported in the literature (Byrd \& Castner 2010; Castro et al. 2010; Lyu et al. 2016). Philonthus longicornis was reported from the previous study conducted on pig carrion (Kaur \& Bala 2018).

Both larvae and adults of Dermestids were observed. Two species of Dermestidae, Dermestes maculatus and Dermestes undulatus, represented the $7 \%$ of the total collected beetle fauna and were observed during the active decay stage but only Dermestes maculatus remained until the dry stage. Larvae of dermestids were the dominant insect fauna during the dry stages.

Necrobia rufipes is known to have a cosmopolitan distribution and widely reported in various forensic studies. Single species $(2 \%)$ of the Cleridae family was collected during the advanced decay stage. However, only a few numbers of these were collected despite it being associated with forensic studies worldwide.

One species in the family Chrysomelidae, Periclitena vigorsi, was observed during one of the experiments. According to Anton et al. (2011), family Chrysomelidae is an accidental visitor to carrion. However, it has been reported in forensic literature (Miralbes 2002; Castro 2011; Lopes, 2012). Further studies need to be conducted to examine their forensic importance. Two species in the family Scarabaeidae, Onthophagus cervus and Onthophagus sp., showing coprophagous behavior were found during the experiments.

We agree that low replication limits the applicability of findings to some extent in legal cases, but this data could represent a valuable baseline for studies aiming to understand decomposition processes and to refine the identification for taxa of forensic importance in poorly studied regions of world such as India which is the seventh largest country in terms of area and it has a varied geographical and climatic conditions.

\section{Conclusion}

To the best of our knowledge, this is the first inventory conducted to study the beetle succession on carrion in India specifically. Necrobia rufipes and Dermestes maculatus are widely studied because of their forensic importance, and both were observed in this study. The presence of such species that has cosmopolitan distribution supports their forensic relevance, but lack of their developmental data is the primary hurdle in using these for the estimation of postmortem interval. There should be more developmental models of beetle species along with their succession information and ecology. More extensive studies need to be performed in order to develop a geographical database on arthropod succession from different habitats and their endemic species which can reinforce the practical use of insect species in forensic cases to estimate the mPMI.

\section{Abbreviations \\ mPMl: Minimum postmortem interval; PAl: Pre-appearance interval; \\ F: Fahrenheit; kg: Kilograms; m: Meters; h: Hours; D.F: Degree of freedom; \\ Fig.: Figure; sp.: Species}

\section{Acknowledgements}

The authors would like to thank Dr. Tomas Lackner (Zoologische Staatssammlung München, Germany) and Pakel Jakubec (Czech University of Life Sciences Prague) for their aid in the identification of Histeridae and Silphidae.

Authors' contributions

Both the authors have contributed in the study. All authors read and approved the final manuscript. 


\section{Funding}

This study was supported by the PhD funding provided by the Department of Science \& Technology, Govt. of India (no. IF 130981).

\section{Availability of data and materials}

Not applicable

\section{Ethics approval and consent to participate}

Not applicable as dead goats are procured from the slaughter house.

\section{Consent for publication}

Not applicable

\section{Competing interests}

The authors declare that they have no competing interests

\section{Author details}

'Department of Zoology \& Environmental Sciences, Punjabi University, Patiala, India. ${ }^{2}$ Department of Zoology \& Environmental Sciences, Punjabi University, Patiala, India.

\section{Received: 12 March 2019 Accepted: 17 October 2019}

Published online: 21 December 2019

\section{References}

Anderson GS, VanLaerhoven SL (1996) Initial studies on insect succession on carrion in southwestern British Columbia. J Forensic Sci 41:617-625

Anton E, Niederegger S, Beutel RG (2011) Beetles and flies collected on pig carrion in an experimental setting in Thuringia and their forensic implications. Med Vet Entomol 25:353-364

Barrato M, Burbano ME, Barreto P (2002) Flies (Calliphoridae, Muscidae) and beetles (Silphidae) from human cadavers in Cali, Colombia. Mem Inst Oswaldo Cruz 97:137-138

Bharti M, Singh D (2003) Insect faunal succession on decaying carcasses in Punjab, India. J Forensic Sci 48:1133-1143

Braack LEO (1987) Community dynamics of carrion-attendant arthropods in tropical Africa woodland. Oecologia 72:402-409

Byrd JH, Castner $J \mathrm{~L}$ (2010) Forensic entomology: the utility of arthropods in legal investigations, 2nd edn. CRC Press, Boca Raton, Florida, USA

Castro HF, Classen AT, Austin EE, Norby RJ, Schadt CW (2010) Soil microbial community response to multiple experimental climate change drivers. Appl Environ Microbiol 76:999-1007

Cornaby BW (1974) Carrion reduction by animals in contrasting tropical habitats. Biotropica 6:51-63

Early M, Goff ML (1986) Arthropod succession patterns in exposed carrion on the island of O'ahu, Hawaiian Islands, USA. J Med Entomol 23:520-531

Eberhardt TL, Elliot DA (2008) A preliminary investigation of insect colonization and succession on remains in New Zealand. Forensic Sci Int 176:217-223

Gill GJ (2011) Decomposition and arthropod succession on above ground pig carrion in rural Manitoba. Technical report TR-06-2005. Canadian Police Research centre, Ottawa

Goff ML, Flynn MM (1991) Determination of postmortem interval by arthropod succession: a case study from the Hawaiian Islands. J Forensic Sci 36:607-614

Grassberger M, Frank C (2004) Initial study of arthropod succession on pig carrion in a central European urban habitat. J Med Entomol 41:511-523

Hwang W, Shiao SF (2011) Dormancy and the influence of photoperiod and temperature on sexual maturity in Nicrophorus nepalensis (Coleoptera: Silphidae). Insect Sci 18:225-233

Kaur P, Bala M (2018) Insect faunal succession studies on pork carrion in Punjab, India. J Ent Res 42(2):287-294

Krikken J, Huijbregts J (2001) Insects as forensic informants: the Dutch experience and procedure. Proc Exp Appl Entomol 12:159-164

Kulshrestha P, Satpathy DK (2001) Use of beetles in forensic entomology. Forensic Sci Int 120:15-17

Kumara TK, Abu Hassan A, Che Salmah MR, Bhupinder S (2009) The infestation of Dermestes ater (De Geer) on a human corpse in Malaysia. Trop Biomed 26(1): $73-79$

Lopes SFT (2012) Forensic entomology: DNA barcoding for Coleoptera identification. Masters Dissertation. University of Lisbon, Portugal.

Lyu Z, Wan LH, Yang YQ, Tang R, Xu LZ (2016) A checklist of beetles (Insecta, Coleoptera) on pig carcasses in the suburban area of southwestern China: A preliminary study and its forensic relevance. J Forensic Leg Med 41:42-48

Mariani R, Garcia- Mancuso R, Varela GL, Inda AM (2014) Entomofauna of a buried body: study of the exhumation of a human cadaver in Buenos Aires, Argentina. Forensic Sci Int 237: 19-26.

Matuszewski S (2011) Estimating the pre-appearance interval from temperature in Necrodes littoralis L. (Coleoptera: Silphidae). Forensic Sci Int 212:180-188

Matuszewski S (2012) Estimating the pre-appearance interval from temperature in Creophilus maxillosus L. (Coleoptera: Staphylinidae). J Forensic Sci 57:136-145

Mayer ACG, Vasconcelos SD (2013) Necrophagous beetles associated with carcasses in a semi-arid environment in Northeastern Brazil: Implications for forensic entomology. Forensic Sci Int 226:41-45

Mazur S (2011) A concise catalogue of the Histeridae (Insecta: Coleoptera) Wydawnictw SGGW. Warszawa. pp. 1-332

Midgley JM, Richards CS, Villet MH (2010) The utility of Coleoptera in forensic investigations. In: Amendt J, Campobasso CP, Goff ML, Grassberger M (eds) Current concepts in forensic entomology. Springer, Dordrecht, Netherlands

Miralbes C (2002) Estudio de la entomofauna asociada a cadáveres en el Alto Aragón (España). Monografías SEA 6:1-94

Moemenbellah-Fard MD, Keshavarzi D, Fereidooni M, Soltani A (2018) First survey of forensically important insects from human corpses in Shiraz, Iran. J Forensic Leg Med 54:62-68

Payne JA (1965) A summer carrion study of the baby Sus scrofa Linnaeus. Ecology 46:592-602

Peacock ER (1993) Adults and larvae of hide, larder and carpet beetles and their relatives (Coleoptera: Dermestidae) and of derodontid beetles (Coleoptera: Derodontidae). In: Handbooks for the identification of British insects, vol 5. London.

Prado e Castro C (2011) Seasonal carrion Diptera and Coleoptera communities from Lisbon (Portugal) and the utility of forensic entomology in legal medicine. PhD Thesis, University of Lisbon, Portugal.

Prado e Castro C, García MD, Martins da Silva P. Faria E Silva I, Serrano A (2013) Coleoptera of forensic interest: a study of seasonal community composition and succession in Lisbon, Portugal. Forensic Sci Int 232:73-83

Ridgeway JA, Midgley JM, Collett IM, Villet MH (2013) Advantages of using development models of the carrion beetles Thanatophilus micans (Fabricius) and T. mutilates (Castelneau) (Coleoptera: Silphidae) for estimating minimum post mortem intervals, verified with case data. Int J Leg Med. 128(1):207-220

Rodriguez WC, Bass WM (1983) Insect activity and its relationship to decay rates of human cadavers in East Tennessee. J Forensic Sci 28:423-432

Ruzicka J, Hava J, Schneider J (2000) Taxonomical and distribution notes on Oriental Silphidae, with description of Nicrophorus sausai sp. n. (Insecta: Coleoptera). Reichenbachia 33:377-384

Ruzicka J, Qubaiova J, Nishikawa M, Schneider J (2015) Revision of Palearctic and Oriental Necrophila Kirby et Spence, part 3: subgenus Calosilpha Portevin (Coleoptera: Silphidae: Silphinae). Zootaxa 4013:451-502

Ruzicka J, Schneider J (1996) Faunistic records of Silphidae from China. Klapalekiana 32:77-83

Ruzicka J, Schneider J (2002) Distributional records of carrion beetles (Coleoptera: Silphidae) from Iran, Afghanistan, Pakistan and north-western India. Klapalekiana 38:213-225

Ruzicka J, Schneider J (2011) Revision of Palaearctic and Oriental Necrophila Kirby \& Spence, part 1: subgenus Deutosilpha Portevin (Coleoptera: Silphidae). Zootaxa 2987:1-12

Ruzicka J, Sipkova H, Schneider J (2011) Notes on carrion beetles (Coleoptera: Silphidae) from India. Klapalekiana 47:239-245

Sharma A, Bala M, Singh N (2018) Five case studies associated with forensically important entomofauna recovered from human corpses from Punjab, India. J Forensic Sci \& Criminal Inves. https://doi.org/10.19080/JFSCI.2018.07.555721

Shin SE, Lee HJ, Park JH, Ko KS, Kim YH, Kim KR, Park SH (2015) The first survey of forensically important entomofauna collected from Medicolegal Autopsies in South Korea. BioMed Res Int. https://doi.org/10.1155/2015/606728

Smith KG (1986) A manual of forensic entomology. The Trustees of British Museum, London

Souza ER, Rafael JA, Filho FFX, Da-Silva-Freitas JO, Oliveira Costa J, Ururahy Rodrigues A (2014) First medicolegal forensic entomology case of central Amazon: a suicide by hanging with incomplete suspension. EntomoBrasilis 7 : $12-15$

Sukontason K, Narongchai P, Kanchai C, Vichairat K, Sribanditmongkol P, Bhoopat T, Kurahashi $\mathrm{H}$ et al (2007) Forensic entomology cases in Thailand: a review of cases from 2000 to 2006. Parasitol Res 101:1417-1423 
Tabor KL, Brewster CC, Fell RD (2004) Analysis of the successional patterns of insects on carrion on southwest Virginia. J Med Entomol 41:785-795

Tabor KL, Fell RD, Brewster CC (2005) Insect fauna visiting carrion in Southwest Virginia. Forensic Sci Int 150:73-80

Varatharajan R, Sen A (2000) Role of entomology in forensic sciences. Current Sci 78:544-546

Villet $\mathrm{MH}$ (2011) African carrion ecosystems and their insect communities in relation to forensic entomology. Pest Technology 5:1-15

\section{Publisher's Note}

Springer Nature remains neutral with regard to jurisdictional claims in published maps and institutional affiliations.

\section{Submit your manuscript to a SpringerOpen ${ }^{\circ}$ journal and benefit from:}

- Convenient online submission

- Rigorous peer review

- Open access: articles freely available online

- High visibility within the field

- Retaining the copyright to your article

Submit your next manuscript at $\boldsymbol{\nabla}$ springeropen.com 